\title{
PROBLEMS OF MILITARY SECURITY CONTRACTORSHIP IN IRAQ AND AFGHANISTAN
}

The issue of military privatization, where we refer both to the privatization of military supply and the privatization of military activities in general, has been very topical, especially in the period of Iraq War, which started in 2003, and later. Various private military companies had, of course, been active even before that (e.g. currently inactive companies Executive Outcomes and Sandline International) and external contractors have been increasingly providing for military supply ever since the introduction of the professional soldier recruitment. Nevertheless, Private Military Security Contractors (PMSCs) spread substantially during the topical conflicts in Iraq and Afghanistan. The work by Thomas R. Mockaitis Soldiers of Misfortune? (Strategic Studies Institute and U.S. Army War College Press, May 2014. ISBN 1-58487613-1) presents the functioning of PMSCs in the above-mentioned conflicts, while focusing on the issue of armed contractors. The author finds that, generally, logistics activities (troop housing and facilities, food service operations, laundry operations etc.) do not represent a problem when carried out by contractors. Armed members of PMSCs participating in U.S. operations are, however, something different. Based on the official reports, the author gives account of some of the most exposed incidents and problems (too early and unnecessary firing during armed escorting, inclusion of local contractors, paying warlords for smooth passage, the culture of impunity etc.), thus brutally revealing the problems of military privatization.

Mockaitis mentions two main levels where decision-makers should pay attention to what a government contract with a PMSC means: i.e. control level and legislation level. Control is difficult, since contracts with private companies are not concluded only by the Department of Defense, but also by other government agencies. It is thus impossible to ensure control from one single point, and difficult to coordinate all U.S. stakeholders involved in operations. As far as international and national (U.S. and the country where the operation is taking place) legislations are concerned, the 
author establishes that PMSC members virtually enjoy immunity from prosecution. It becomes perfectly clear, both, from the Mockaitis' monograph as well as from other sources that the military as well should be familiar with the problem of PMSC members' participation in operations. The cooperation of national armed forces (an interesting fact is that Mockaitis capitalizes the word Soldier when referring to members of national armed forces) and contractors necessarily requires certain common bases. In this respect, military competence represents the least of a problem, since PMSC members are usually well-trained and have military experience. It can be established on the basis of a number of incidents that contractors in themselves represent a risk, since they do not abide by the principle of the minimum use of force and very quickly become involved in an armed conflict. The cooperation of national military with such entities does not only pose a direct threat to soldiers, but also worsens the attitude of the local population towards the armed forces in the area. Instead of contributing to the success of the operation, the contractors threaten its success. Mockaitis, however, underlines that all contractors cannot be equated. A number of them do a good and professional job. Nevertheless, the incidents provoked by the minority (Blackwater has proved to be an especially notorious company) reflect unfavorably on all PMSCs.

In the conclusion of his monograph, which is short, though, (64 pages) considering the topicality and appeal of the discussed problem, Mockaitis recaps the experiences drawn from the functioning of military security companies in Iraq and Afghanistan and provides a few recommendations which would be good to take into consideration when hiring these companies to do military work. 